Канд. техн. наук В.В. Кулешов

\title{
АНАЛІЗ ПЕРСПЕКТИВ РОЗВИТКУ СОРТУВАЛЬНИХ СТАНЦІЙ ЗА КОРДОНОМ ТА НА ЗАЛІЗНИЦЯХ УКРАЇНИ В УМОВАХ РЕФОРМУВАННЯ ТРАНСПОРТУ
}

\section{Представив д-р техн. наук, професор О.М. Огар}

Постановка проблеми у загальному вигляді, іiї зв'язок 3 важливими науковими та практичними завданнями. Основне призначення сортувальних станцій у вузлових точках мережі - переробка вагонопотоків, розформування та формування поїздів дальніх призначень. Для виконання цих робіт типова 
сортувальна станція має спеціальні колії, маневрові засоби, сортувальний комплект (систему), що включає, як правило, парки приймання, сортування, відправлення, сортувальні пристрої, пристрої підприємств локомотивного, вагонного господарств та інші.

У Європі споруджувалися переважно односторонні сортувальні станції, що мають об'єднані парки колій для всіх напрямків руху поїздів. У США перевага була віддана двостороннім станціям. Техніка i технологія переробки вагонопотоків особливо інтенсивно вдосконалювалася у країнах Західної Європи (Німеччина, Франція, Великобританія) і США, а останнім часом в Японії. Великий внесок у проектування і розвиток сортувальних станцій зробили фахівці залізничного транспорту Росії, України, Білорусі та інших держав СНД.

На початку незалежності у 1991 р. на мережі залізниць України перероблялося i відправлялося понад 850 млн т вантажів на рік. Через 8 років цей обсяг зменшився на дві третини із темпами $12,5 \%$ на рік, протягом наступних 8 років почав поступово збільшуватися 3 темпами 5,6 \% на рік. У зв'язку із переходом економіки країни до ринкових відносин виникає необхідність в аналізі стану і перспектив розвитку сортувальних станцій залізниць України та дослідженні закордонного досвіду експлуатації вказаних станцій.

Аналіз останніх досліджень i публікацій. У нормативних документах, підручниках та навчальних посібниках [1-6] не в повній мірі відображено питання раціонального розташування сортувальних станцій та їх інформаційні технології, за допомогою яких можливо забезпечити підвищення якості перевезень. У дослідженнях [7-10] було розглянуто сучасні підходи до визначення технічного рівня сортувальних станцій при перерозподілі сортувальної роботи 3 урахуванням ринкових умов та прогнозування попиту на вантажні перевезення. Малодослідженим на даний момент $\epsilon$ питання перспектив розвитку сортувальних станцій на базі удосконалення взаємодії залізничних адміністрацій і власників рухомого складу на умовах ресурсозбереження. При цьому слід зазначити, що в Україні частка власних вагонів складає більше 65 \% від загального парку вагонів.

Мета дослідження. Аналіз перспектив розвитку сортувальних станцій за кордоном i на залізницях України в умовах реформування залізничного транспорту.

Основна частина. Внаслідок скорочення обсягів перевезень на ряді залізниць України частка сортувальних станцій віднесена до дільничних або вантажних. Наприклад, на Південній залізниці за призначенням i основним характером роботи визначено 3 сортувальних станції (Основа, Кременчук, Куп'янськ-Сортувальний) та 11 дільничних станцій (Лозова, Мерефа, ХарківСортувальний, Люботин, Смородине, Гребінка, Полтава-Південна, Прилуки, Ромодан, Ромни, Куп'янськ-Вузловий).

У зв'язку із зменшенням обсягів перевезень та переходом на контейнерні перевезення автомобильним транспортом останнім часом багато сортувальних станцій закриваються. Зокрема, закриті всі сортувальні станції Великобританії, Норвегії, Данії, Японії та Австралії.

Відомо, що на залізницях США, Канади, Франції, ФРН здійснено роботи 3 модернізації існуючих сортувальних станцій, оснащених сучасним обладнанням. На цих станціях у більшості випадків концентрується сортувальна робота, що виконувалася раніше на декількох невеликих непродуктивних станціях. У результаті концентрації досягається прискорення просування вагонів, зменшення кількості працівників, числа маневрових локомотивів i в кінцевому підсумку зниження експлуатаційних витрат [5]. Нове залізничне будівництво практично 
не ведеться. Надмірність мережі США дозволила оптимізувати іiі конфігурацію, вивести $з$ експлуатації нерентабельні лінії. Особливості реконструкції сортувальних станцій закордоном такі:

- застосування сортувальних станцій одностороннього типу. Їх переробна спроможність при сучасному обладнанні значно підвищилася і у багатьох випадках забезпечує прогнозовані розміри роботи;

- укладання великої кількості колій в основних сортувальних парках і побудова, крім того, на багатьох станціях з великим місцевим вагонопотоком групувальних або місцевих парків 3 додатковим сортувальним комплексом для повторного сортування;

- використання сучасного обладнання, що забезпечує автоматизацію гальмування, управління стрілками i інформатизацію інших процесів на основі сучасних телекомунікаційних систем та ін.

Поряд 3 цим розвиток сортувальних станцій у кожній країні має деякі особливості.

У США функціонує більше 60 односторонніх (ОСС) і двосторонніх (ДСС) сортувальних станцій. Станція Конвей має 107 колій в обох сортувальних парках i переробну спроможність 9000 ваг/доб. У числі односторонніх великі станції Янг, Гейтвей, Альфред Перлман та ін. У парках приймання і відправлення число колій сягає 20. Також $є$ додаткові парки (для відстою порожніх, несправних вагонів та ін.) На односторонніх станціях число колій менше (в об'єднаному парку приймання приблизно 12-15 колій), а в парках відправлення по 5-6 колій у кожному напрямку.

У Канаді п'ять великих автоматизованих односторонніх станцій: Монктон, Монреаль, Симінгтон, Торонто і Алайт. На станції Монреаль послідовно 3 основним сортувальним парком із 84 коліями розміщується другий сортувальний парк (40 колій) для сортування місцевих вагонів і формування багатогрупних поїздів 3 механізованою двопозиційною гіркою.
Для залізниць Франції також характерна концентрація сортувальної роботи на меншій кількості станцій. Характерною є наявність великої кількості колієпровідних розв'язок маршрутів приймання та відправлення поїздів i внутрішньостанційних пересувань. Ряд колишніх двосторонніх станцій перебудовано в односторонні (Вкльнев, Жеврей, Бурже).

Особливістю організації вантажного руху та сортувальної роботи на залізницях Франції є спеціалізація станцій або парків для прискорених вантажних поїздів. В одних випадках для цього призначаються окремі станції (Лілль-Сен-Совер), в інших одна система парків служить для переробки прискорених, інша - звичайних вантажних поїздів (станції Трапп, Сотвіль). Формування звичайних поїздів концентрується на 38 , а прискорених - на 29 станціях.

У Федеративній Республіці Німеччини проводиться концентрація сортувальної роботи, яка супроводжується повним або частковим закриттям окремих малопотужних станцій. Кілька великих сортувальних станцій (Брауншвейг, Гремберг, Мангейм, Корнвестгейм, Бебра та ін.) реконструйовані з метою збільшення переробної спроможності. Двосторонні станції Брауншвейг, Оффенбург, Соте перевлаштовані в односторонні. На двосторонній станції Мангейм реконструйована сортувальна система, що працює зі сходу на захід, при цьому число колій в сортувальному парку було збільшено до 42 за рахунок допоміжної (третьої) системи. У Гамбурзькому вузлі двостороння сортувальна станція Maschen $\mathrm{Rbf}$ (Махен) $3 \quad 64$ i 48 коліями у сортувальних парках має переробну спроможність 9200 вагонів на добу. При реконструкції число колій у парках приймання збільшилось до 12, в парках відправлення - до 9, у сортувальному - до 32-42 колій. Довжина колій у парках приймання і відправлення 700-800 м, у сортувальному $-800-900$ м. 
У Швейцарії сортувальна робота сконцентрована на 15 основних станціях (у тому числі на 6 прикордонних) 3 переробкою від 1500 до 6000 вагонів (Женева Кіассо, Лозанна) і на 22 допоміжних. На станції Цюріх-Ліматталь запроектовано 6 колій у парку приймання (довжиною 750 м), 65 колій у сортувальному парку (довжиною $650-850$ м) i 15 колій у парку відправлення (довжиною 750 м). У хвості сортувального парку розташована допоміжна гірка із підгірковим парком на 12 колій для формування місцевих і багатогрупних поїздів.

У Польщі сортувальна робота у 2012 р. сконцентрована на 55 станціях (26 основних і 29 допоміжних) замість 102 станцій.

В Японії є 37 сортувальних станцій, у тому числі 6 гіркових. Станції Коріяма, Такасакі побудовані за комбінованою схемою 3 розташуванням приймальних парків паралельно сортувальному. У сортувальному парку 36 колій, а в двох приймально-відправних - по 10. Переробна спроможність цієї станції 4300 вагонів на добу.

Основні завдання подальшого розвитку сортувальних станцій при зростанні розмірів вантажних перевезень у власному парку вагонів і збільшенні розмірів переробки вагонопотоків полягають у підвищенні їх пропускної i переробної спроможності при використанні сучасних методів експлуатації та оснащенні досконалими засобами автоматики, телемеханіки і зв'язку.

Сортувальну станцію, яка формує поїзди на магістральні лінії, слід розглядати не ізольовано, а у взаємодії 3 іншими сортувальними станціями даного полігону мережі, для чого можливо застосувати метод рою часток (МРЧ) (англ. Particle Swarm Optimization, PSO) - метод чисельної оптимизації, для використання якого не потрібно знати точного градієнта функції, що оптимізується. МРЧ оптимізує функцію, підтримуючи популяцію можливих рішень, названих частками, i переміщуючи ці частки в просторі рішень згідно із простою формулою. Перевезення підкорюються принципу найкращого знайденого в цьому просторі положення, що постійно змінюється при знаходженні частками більш вигідних положень [12].

Основні відомості про колійний розвиток сортувальних станцій України та закордонних залізниць наведено у таблиці.

Позначення: П - парк приймання; Г сортувальна гірка; C - сортувальний парк; В - парк відправлення; Тр - транзитний парк; ПВ - суміщений приймальновідправний парк; МП - парк для місцевих вагонів; РП - ранжирний парк.

Тривалість перебування вагона 3 переробкою на сортувальній станції показник, який потрібно мінімізувати:

$$
f\left(T^{n}\right) \rightarrow T \rightarrow \min ,
$$

де $n$ - кількість вагонів різних власників та операторів перевезень як множина часток у рої, кожна $з$ яких має координату $x_{i} \in T^{n}$ у просторі рішень і швидкість доставки вантажу $v_{i} \in T^{n}$;

$$
\begin{aligned}
& p_{i}-\text { краще з відомих положень частки } i \text {; } \\
& g-\text { найкращий відомий стан рою в }
\end{aligned}
$$
цілому.

Для кожної частки $i=1,2,3 \ldots, n$ потрібно виконати таке:

1) згенерувати початкове положення частки за допомогою випадкового вектора $x_{i} \sim U\left(b_{l o}, b_{u p}\right)$, що має багатовимірне рівномірне розподілення $\left(b_{\mathrm{lo}}\right.$ i $\mathrm{b}_{\mathrm{up}} \quad-$ відповідно нижня і верхня границі простору рішень);

2) привласнити кращому відомому положенню частки його початкове значення: $x_{i} \rightarrow p_{i}$. Якщо $f\left(\mathrm{p}_{\mathrm{i}}\right)<f(\mathrm{~g})$, то оновити найкращий відомий стан рою: $p_{i} \rightarrow g$;

3) привласнити значення швидкості частки:

$$
v_{i} \sim U\left(-\left(b_{u p}-b_{l o}\right),\left(b_{u p}-b_{l o}\right)\right) .
$$


Основні відомості про колійний розвиток сортувальних станцій України та закордонних залізниць

\begin{tabular}{|c|c|c|c|c|c|c|c|c|c|c|}
\hline \multirow[b]{2}{*}{ Держава } & \multirow{2}{*}{$\begin{array}{c}\text { Кіль- } \\
\text { кість } \\
\text { СС }\end{array}$} & \multirow[b]{2}{*}{ Назва СC } & \multirow[b]{2}{*}{$\begin{array}{l}\text { Тип } \\
\text { СС }\end{array}$} & \multirow[b]{2}{*}{ Опис схеми СС } & \multicolumn{4}{|c|}{ Кількість колій у парках } & \multirow{2}{*}{$\begin{array}{c}\text { Корисна } \\
\text { довжина } \\
\text { колій, м }\end{array}$} & \multirow{2}{*}{$\begin{array}{c}\text { Оприлюднена } \\
\text { переробна } \\
\text { спроможність, } \\
\text { ваг/доб }\end{array}$} \\
\hline & & & & & $\Pi$ & $\mathrm{C}$ & $\mathrm{B} / \mathrm{Tp}$ & $\Gamma \mathrm{p}$ & & \\
\hline \multirow{3}{*}{ Україна } & & Основа & ДСС & $\begin{array}{c}-\mathrm{B}_{1-\mathrm{C}_{1}-\Gamma_{1}-\Pi_{1^{-}}}-\Pi_{2}-\Gamma_{2}-\mathrm{CB}_{2^{-}} \\
-\mathrm{Tp}-\end{array}$ & $8+8$ & $27+20$ & $\begin{array}{l}12 / \\
10\end{array}$ & - & $594-1023$ & - \\
\hline & & $\begin{array}{l}\text { Купянськ- } \\
\text { Сорт. }\end{array}$ & ДСС & $\begin{array}{c}-\mathrm{C}_{1^{-}} \Gamma_{1_{1}-\Pi_{1^{-}}} \\
-\Pi_{2}-\Gamma_{2}-\mathrm{C}_{2}-\mathrm{B}_{2^{-}}\end{array}$ & $5+7$ & $15+22$ & $4+7 / 4$ & - & $792-1161$ & - \\
\hline & & Кременчук & $\mathrm{OCC}$ & $-П-\Gamma-\mathrm{C}-\mathrm{B}-$ & 8 & 24 & 15 & - & $847-991$ & - \\
\hline \multirow[b]{2}{*}{ Росія } & \multirow[b]{2}{*}{73} & $\begin{array}{l}\text { Скатеринбург- } \\
\text { Сортувальний }\end{array}$ & ДСС & $\begin{array}{l}-\Pi_{1}-\Gamma_{1}-C_{1}-B_{1-} \\
-B_{2}-C_{2}-\Gamma_{2}-\Pi_{2-}\end{array}$ & $8+11$ & $36+36$ & $8+15$ & - & - & 8000 \\
\hline & & $\begin{array}{c}\text { Санкт- } \\
\text { Петербург- } \\
\text { Сортувальний } \\
\text {-Московський }\end{array}$ & ДСС & $\begin{array}{l}-\Pi_{1}-\Gamma_{1}-C_{1}-B_{1-} \\
-B_{2}-C_{2}-\Gamma_{2}-\Pi_{2-}\end{array}$ & $9+14$ & $35+27$ & $\begin{array}{c}14+ \\
15\end{array}$ & - & - & 7000 \\
\hline \multirow{3}{*}{ США } & \multirow{3}{*}{$\begin{array}{c}\text { більше } \\
60\end{array}$} & Бейли Ярд & ДСС & - & - & $50+64$ & - & - & - & - \\
\hline & & Конвей & ДСС & $\begin{array}{c}-\Pi_{1}-\Gamma_{1}-\mathrm{C}_{1}-\mathrm{B}_{1-} \\
-\mathrm{M}-\mathrm{P} \Pi- \\
-\mathrm{B}_{2}-\mathrm{C}_{2}-\Gamma_{2}-\Pi_{2-}\end{array}$ & 20 & 107 & 20 & - & $\begin{array}{c}1200- \\
1700\end{array}$ & 9000 \\
\hline & & Янг & $\mathrm{OCC}$ & $\begin{array}{c}-\Pi_{1}-\Gamma-\mathrm{C}-\mathrm{M} П-Р П \\
-\mathrm{B}_{1^{-}} /-\mathrm{B}_{2}-\end{array}$ & 15 & 72 & $5+6$ & - & $600-1670$ & - \\
\hline Канада & 5 & Монреаль & $\mathrm{OCC}$ & $-\Pi-\Gamma-\mathrm{C}-\mathrm{B}-$ & 19 & $67-84$ & 13 & - & - & - \\
\hline Франція & 12 & Вуаппі & $\mathrm{OCC}$ & -П-Г-С-B- & 14 & 48 & 10 & - & - & $3000-3500$ \\
\hline$\Phi Р Н$ & & Махен & ДСС & $\begin{array}{l}-\Pi_{1}-\Gamma_{1}-C_{1}-B_{1-} \\
-B_{2}-C_{2}-\Gamma_{2}-\Pi_{2-}\end{array}$ & 12 & $64+48$ & 9 & - & - & 9200 \\
\hline Швейцарія & 12 & $\begin{array}{c}\text { Цюріх- } \\
\text { Ліматталь }\end{array}$ & OCC & $-П-Г-C-B-$ & 6 & 65 & 15 & 12 & - & - \\
\hline Японія & 37 & Коріяма & $\mathrm{OCC}$ & $-П-Г-C-B-$ & 10 & 35 & 10 & - & - & 4300 \\
\hline
\end{tabular}


До досягнення заданої кількості ітерацій або необхідного значення цільової функції повторювати алгоритм:
- згенерувати випадкові вектори $r_{p}$, $\mathrm{r}_{\mathrm{g}} \sim U(0,1)$;

- поновити швидкість часток:

$$
\mathrm{v}_{\mathrm{i}} \leftarrow \omega \mathrm{v}_{\mathrm{i}}+\varphi_{\mathrm{p}} \mathrm{r}_{\mathrm{p}} \times\left(\mathrm{p}_{\mathrm{i}}-\mathrm{x}_{\mathrm{i}}\right)+\varphi_{\mathrm{g}} \mathrm{r}_{\mathrm{g}} \times\left(\mathrm{g}-\mathrm{x}_{\mathrm{i}}\right)
$$

де операція $\times$ означає покомпонентне множення;

- поновити положення частки переносом $x_{i}$ на вектор швидкості:

$$
x_{i} \leftarrow \mathrm{x}_{\mathrm{i}}+\mathrm{v}_{\mathrm{i}}
$$

Якщо виконується умова $\left(f\left(x_{i}\right)<f\left(p_{i}\right)\right)$, то поновити краще відоме положення частки $x_{i} \rightarrow p_{i}$.

Якщо виконується умова $\left(f\left(p_{i}\right)<f(g)\right)$, то поновити кращий відомий стан рою в цілому $p_{i} \rightarrow g$.

Tепер $g$ містить найкраще із знайдених рішень перевезення вагонів різних власників та оператора перевезень.

Параметри $\omega, \varphi_{\mathrm{p}}$, і $\varphi_{\mathrm{g}}$ вибираються обчислювачем i визначають поведінку та ефективність методу в цілому.

Теоретичні дослідження i накопичений досвід переконливо показують, що обгрунтована концентрація сортувальної роботи на обмеженому числі потужних $\mathrm{i}$ добре технічно оснащених станцій дає можливість:

- зменшити витрати на розвиток станцій i, зокрема, на обладнання гірок;

- знизити число переробок вагонів на шляху прямування i прискорити їx просування, зменшити простої вагонів, а також вартість сортувальної роботи на мережі залізниць;

- підвищити рівень використання технічних пристроїв i продуктивність праці, забезпечити високу економічну ефективність засобів автоматизації. \begin{tabular}{lllr}
\multicolumn{2}{c}{ Висновки 3 дослідження } & i \\
перспективи, подальший & розвиток & y \\
даному напрямку. & Узагальнення
\end{tabular} закордонного досвіду дозволяе зробити висновок, що роботи в напрямі автоматизації сортувальної роботи, використання ЕОМ при плануванні i управлінні усім сортувальним процесом ведуться як у нашій країні, так і в ряді країн (Росії, США, Канаді, ФРН, Японії та ін.). Однак повністю відпрацьованих систем ще немає.

Що ж стосується принципів проектування за кордоном односторонніх сортувальних станцій 3 об'єднаними парками, то вони не є для України новими. Заслуговує на увагу укладання великого числа сортувальних колій в основних сортувальних парках та спорудження у багатьох випадках додаткових парків для повторного сортування та групування місцевих вагонів, що прямують на станції прилеглих ділянок, вантажні райони та під'їзі колії. Також становлять інтерес схеми станцій з коліями в сортувальному парку меншої корисної довжини у порівнянні 3 парками приймання i відправлення, що дозволяє при реконструкції розмістити станцію на більш короткій площадці без великих робіт 3 реконструкції підходів головних колій.

Сортувальну станцію, яка формує поїзди із вагонів різних власників та операторів перевезень на магістральні лінії, слід розглядати не ізольовано, а у взаємодії 3 іншими сортувальними станціями даного полігону мережі. Для чого можливо застосувати метод чисельної оптимізації, наприклад, метод рою часток.

При інженерному проробленні планів формування i графіка руху поїздів 
необхідне урахування ринкових методів та удосконалення порядку планування перевезень.

Існуючу систему технічного нормування експлуатаційної роботи залізниць необхідно замінити технологічним нормуванням використання парків рухомого складу на принципах екстериторіальності у рамках динамічних транспортних схем перевезень вантажів у вагонах певного типу, сполучаючи при цьому методи керування знеособленим парком i адресною прив'язкою вагонів конкретних операторів перевезень.

\section{Список літератури}

1. Концепція державної програми реформування залізничного транспорту України [Текст] / Схвалено розпорядженням КМУ 27.12.2006. №651-р. - К.: Магістраль, № 1 (1179). 10-16 січня 2007 р. - С. 6.

2. Транспортна стратегія України на період до 2020 року. Схвалена розпорядженням КМУ 16.12.2009 р. № 1555-p.: [Електронний ресурс]. - Режим доступу: www/URL: http://www.mintrans.gov.ua/uk/discussion/15621.html/ 10.12.2009. - Загол. з екрана.

3. Програма економічних реформ України на 2010-2014 рр.: [Електронний ресурс]. Режим доступу: www/URL: president.gov.ua〉docs/Programa_reform_FINAL_1.pdf. - Загол. 3 екрана.

4. ДБН В.2.3-19-2008. Споруди транспорту. Залізничні колії 1520 мм. Норми проектування [Текст]. Замінює СНиП ІІ-39-76; введ. 26.01.2008. - К.: Мінрегіонбуд України, 2008. - $122 \mathrm{c}$.

5. Особенности и характерные примеры развития зарубежных сортировочных станций: [Электронный ресурс]. - Режим доступа: www/URL: http://www.jd-st.ru/4-sortirovochnyestancii/6-osobennosti-i-xarakternye-primery-razvitiya-zarubezhnyx-sortirovochnyx-stancij/.

Загол. с экрана.

6. Крячко, В.I. Розрахунки і проектування основних пристроїв на залізничних станціях [Текст]: навч. посібник / В.І. Крячко. - Харків: УкрДАЗТ, 2000.

7. Сіконенко, Г.М. Удосконалення методів визначення технічного рівня сортувальних станцій [Текст]: автореф. дис.... канд. техн. наук: 05.22.20 / Г.М. Сіконенко; Укр. держ. акад. залізнич. тр-ту. - Харків, 2005. - 18 с.

8. Бутько, Т.В. До питання визначення оптимальної кількості сортувальних станцій [Текст] / Т.В. Бутько, М.І. Данько, Г.М. Сіконенко // Коммунальное хозяйство городов. Харьков: Техника, 2002. - № 45. - С. $237-242$.

9. Данько, М.I. Формування вимог до технології взаємодії залізничних адміністрацій і власників рухомого складу [Текст] / М.І. Данько, Д.В. Ломотько, В.М. Запара, В.В. Кулешов // Зб. наук. праць. - Харків: УкрДАЗТ, 2011. - Вип. 124. - С. 5-11.

10. Данько, М.І. Удосконалення організаційно-технологічної моделі використання вантажних вагонів різної форми власності на залізницях України [Текст] / М.I. Данько, Д.В. Ломотько, В.В. Кулешов // Зб. наук. праць. - Харків: УкрДАЗТ, 2012. - Вип. 129. - С. 512.

11. Кулешов, В.В. Удосконалення інформаційної технології роботи з вагонами різних форм власності з метою оптимізації пропускної спроможності залізничних транспортних систем [Текст] / В.В. Кулешов // Зб. наук. праць. - Харків: УкрДАЗТ, 2011. - Вип. 124. C. 83-90.

12. Метод рою часток [Електронний ресурc]. - Режим доступу: www/URL: http://uk.wikipedia.org/wiki/. - Загол. з екрана. 
Ключові слова: вагон, колійний розвиток, концентрація сортувальної роботи, метод рою часток, реформування залізничного транспорту, сортувальна станція.

\section{Анотації}

Виконаний аналіз колійного розвитку сортувальних станцій України та закордонних залізниць. Виділені основні питання закордонного досвіду застосовування систем автоматизації процесу сортувальної роботи. Для чисельної оптимизації роботи сортувальної станції у взаємодії з іншими сортувальними станціями даного полігону мережі можливо застосувати метод рою часток. Обгрунтована концентрація сортувальної роботи на обмеженому числі потужних і добре технічно оснащених станцій.

Выполнен анализ путевого развития сортировочных станций Украины и зарубежных железных дорог. Выделены основные вопросы зарубежного опыта применения систем автоматизации процесса сортировочной работы. Для оптимизации работы сортировочной станции во взаимодействии с другими сортировочными станциями данного полигона сети возможно применить метод роя частиц. Обоснована концентрация сортировочной работы на ограниченном числе мощных и хорошо технически оснащенных станций.

The analysis of the gridiron sorting stations in Ukraine and foreign railways. The basic questions of international experience of process automation systems sorting work. To optimize the yard in collaboration with other yards of landfill network may use the method of particle swarm. Justified the concentration of sorting on a limited number of powerful and technically wellequipped stations. 